\title{
Effects of Brown Coal Application on Heavy Metal Uptake by Plants
}

\author{
L. VERMES and I. KÁDÁR
}

Szent István University, Faculty of Horticultural Sciences, Budapest and Research Institute for Soil Science and Agricultural Chemistry (RISSAC) of the Hungarian Academy of Sciences, Budapest

\section{Introduction}

Soil contamination caused by heavy metals and other pollutants is one of the major environmental problems all over the world, therefore the remediation of contaminated soils is of high interest. Among the many trials aiming to find the technically, economically and also environmentally most effective remediation technologies, one of the most important fields is to develop methods for in situ remediation using natural material as much as possible. In case of heavy metals earlier studies (KÜHNERT et al., 1989; VADÁSZ, 1997) show that some brown coals with high humic acid/fulvic acid content may have a significant function in the immobilization of pollutants in soil, and can play an important role in the remediation of contaminated sites. In the present experiments brown coal from the Central Transdanubian coal-basin of Eocene origin was used to demonstrate its effects on heavy metal immobilization in Hungarian calcareous chernozem soil (VERMES \& KÁDÁR, 2001).

\section{Material and Methods}

Crushed brown coal from the Balinka coal mine was used in both pot and field experiments carried out in 1999-2001. The most important characteristics of the coal applied are summarized in Tables 1 and 2. The experimental site (Research Station Nagyhörcsök) is located in the Danube Valley on a calcareous loamy chernozem formed on loess, at a height of $140 \mathrm{~m}$ above sea level. The climate is continental, the mean annual temperature is $11^{\circ} \mathrm{C}$, with an average annual precipitation of $576 \mathrm{~mm}$.

Correspondence to: Dr. László VERMES, Szent István University, Faculty of Horticultural Sciences, Department of Soil Science and Water Management, H-1114 Budapest, Villányi út 35-43. E-mail: vermes@omega.kee.hu 
Table 1

Main characteristics of the brown coal from Balinka

\begin{tabular}{|c|c|c|}
\hline $\begin{array}{l}\text { Determined properties, } \\
\text { composition }\end{array}$ & $\begin{array}{c}\text { Measurement } \\
\text { units }\end{array}$ & $\begin{array}{c}\text { Measured } \\
\text { values }\end{array}$ \\
\hline \multicolumn{3}{|l|}{ Grain size distribution } \\
\hline$>5 \mathrm{~mm}$ & $\%$ & 4.3 \\
\hline $1-5 \mathrm{~mm}$ & $\%$ & 84.9 \\
\hline$<1 \mathrm{~mm}$ & $\%$ & 10.8 \\
\hline Volume weight & $\mathrm{kg} / \mathrm{dm}^{3}$ & 0.9 \\
\hline $\mathrm{pH}\left(\mathrm{H}_{2} \mathrm{O}\right)$ & & 7.6 \\
\hline Dry Matter Content (DM) & $\%$ & 95.0 \\
\hline Total Oganic Matter (TOM) & $\mathrm{DM} \%$ & 61.2 \\
\hline Ashes & DM \% & 38.8 \\
\hline Total Oganic Carbon (TOC) & DM \% & 44.2 \\
\hline Humic-acid content & $\%$ of Ashes & 21.1 \\
\hline Humic-acid content & DM \% & 13.4 \\
\hline Humic-acid content & TOM \% & 8.2 \\
\hline Total Humificated Organic Carbon & TOM \% & 44.2 \\
\hline Total Nitrogen & TOM \% & 0.8 \\
\hline Humic-acid Carbon content & TOC $\%$ & 10.7 \\
\hline Fulvic-acid Carbon content & TOC $\%$ & 0.9 \\
\hline
\end{tabular}

Table 2

Total mineral element content of the used Balinka brown coal

\begin{tabular}{|c|c||c|c|}
\hline Element & $\mathrm{mg} / \mathrm{kg}$ dry matter & Element & $\mathrm{mg} / \mathrm{kg}$ dry matter \\
\hline $\mathrm{S}$ & 50100 & $\mathrm{P}$ & 62 \\
$\mathrm{Ca}$ & 46300 & $\mathrm{Zn}$ & 26 \\
$\mathrm{Al}$ & 20500 & $\mathrm{Cr}$ & 23 \\
$\mathrm{Fe}$ & 16600 & $\mathrm{Ni}$ & 20 \\
$\mathrm{Mg}$ & 4290 & $\mathrm{Cu}$ & 14 \\
$\mathrm{Na}$ & 2600 & $\mathrm{~Pb}$ & 5 \\
$\mathrm{~K}$ & 240 & $\mathrm{As}$ & 5 \\
$\mathrm{Sr}$ & 800 & $\mathrm{Co}$ & 4 \\
$\mathrm{~B}$ & 180 & $\mathrm{Mo}$ & 2 \\
$\mathrm{Mn}$ & 169 & $\mathrm{Cd}$ & 0.4 \\
$\mathrm{Ba}$ & 71 & $\mathrm{Se}$ & 0.2 \\
\hline
\end{tabular}

The characteristic properties of the plough layer of the soil are: clay: 2025\%; silt: $50-55 \%$; sand: $15-20 \%$; humus: $\sim 3 \%$; $\mathrm{CaCO}_{3}: 5 \%$; total C: $1.7-$ 
2.0\%; total $\mathrm{N}: 0.2 \% ; \mathrm{pH}\left(\mathrm{H}_{2} \mathrm{O}\right): 7.5-8 ; \mathrm{pH}(\mathrm{KCl}): 7-7.8 ; \mathrm{CEC}: 30 \mathrm{meq} / 100 \mathrm{~g}$ soil. Available nutrients in the soil are as follows: ammonium lactate soluble AL- $\mathrm{P}_{2} \mathrm{O}_{5} 60-80 \mathrm{mg} / \mathrm{kg} ;$ AL-K $2 \mathrm{O}: 140-160 \mathrm{mg} / \mathrm{kg} ; \mathrm{KCl}$-soluble $\mathrm{Mg} 150-180$ $\mathrm{mg} / \mathrm{kg} ; \mathrm{KCl}+$ EDTA $\mathrm{Mn} 80-150 \mathrm{mg} / \mathrm{kg} ; \mathrm{Cu} 2-3 \mathrm{mg} / \mathrm{kg} ; \mathrm{Zn} 1-2 \mathrm{mg} / \mathrm{kg}$. The experimental soil is well supplied with $\mathrm{Ca}, \mathrm{Mg}$ and $\mathrm{Mn}$; moderately supplied with $\mathrm{N}$ and $\mathrm{K}$; and poorly supplied with $\mathrm{P}$ and $\mathrm{Zn}$. The water table is found at a depth of 13-15 m and has no affect on soil process or fertilizer effectivity. The test plant of the pot experiments carried out at the Szent István University was lettuce (Lactuca sativa), using 10 seeds in each pot. Maize (Zea mays), winter barley (Hordeum vulgare - in 2000) and rape (Brassica napus - in 2001) crops were grown in field trials at the Nagyhörcsök Experimental Station.

The soil in the pot experiments was contaminated artificially with the following different heavy metal compounds: $400 \mathrm{mg} / \mathrm{kg} \mathrm{K} \mathrm{KrO}_{7}, 100 \mathrm{mg} / \mathrm{kg}$ $\mathrm{NiSO}_{4} \times 7 \mathrm{H}_{2} \mathrm{O}, 30 \mathrm{mg} / \mathrm{kg} \mathrm{Pb}(\mathrm{Ac})_{2}, 2 \mathrm{mg} / \mathrm{kg} \mathrm{Cd}(\mathrm{Ac})_{2}, 4000 \mathrm{mg} / \mathrm{kg} \mathrm{ZnCl}{ }_{2}$ and 4 $\mathrm{mg} / \mathrm{kg} \mathrm{HgCl}$. The Balinka coal was mixed with the soil in four portions: $0 \%$, $25 \%, 50 \%, 75 \%$. The combined effects of heavy metals and coal application on the germination and green biomass of the test plant were investigated in this pre-experiment.

Based on the results of the pot experiment, in the field experiment carried out in Nagyhörcsök, the Balinka coal was applied in a rate equal to $40 \mathrm{t} / \mathrm{ha}$ dry weight. In the field experiments the combined effects of heavy metals and coal application on the green biomass and heavy metal uptake of the test plants, as well as on the heavy metal content of the soil were studied.

In the pot experiment each treatment was repeated four times, and the field trials were set up with 3 replications. Management practices, observations, measurements, sampling and analytical methods, as well as data processing and evaluation methods were performed according to the standardized methodology described earlier (KÁDÁR, 1995; VERMES \& KÁDÁR, 2001).

\section{Results and Discussion}

As it was mentioned above, the pot experiment was only a pre-experiment to find the best coal dosage which has a positive effect on heavy metal immobilization in contaminated soil. Without going into the details of this experiment, and based on the average green biomass results of the test plant (Table 3) it can be stated that - as compared to the control treatment $(0 \%$ coal addition to the soil) - the coal treatments increased the biomass yield of the plant, and a significant difference was observed between the $25 \%$ and $50 \%$ coal mixture treatments, too. No significant difference was found between the $50 \%$ and $75 \%$ coal mixture treatments. It could also be reported that this yield increasing effect depended on the type of heavy metal load, but was independent of the concentration of the load. This shows that the effect of coal addition is uniform, 
Table 3

Some results of the pot experiment carried out with Balinka brown coal application to heavy metal contaminated soil, 1999

\begin{tabular}{|c|c|c|c|}
\hline $\begin{array}{c}\text { Treatment } \\
\text { code }\end{array}$ & $\begin{array}{c}\text { Mixing ratio } \\
\text { coal to soil } \\
\%\end{array}$ & $\begin{array}{c}\text { Green biomass yield } \\
\text { of lettuce } \\
\text { g/pot }\end{array}$ & $\begin{array}{c}\text { Dry matter yield } \\
\text { of lettuce } \\
\text { g/pot }\end{array}$ \\
\hline A & 0 & 0.3 & 0.04 \\
B & 25 & 0.8 & 0.14 \\
C & 50 & 1.36 & 0.27 \\
D & 75 & 1.42 & 0.19 \\
$\mathrm{LSD}_{5 \%}$ & & 0.40 & 0.08 \\
\hline
\end{tabular}

and it is realized by the binding process of heavy metal which seems to be directly proportional with the brown coal quantity applied. Finally, the experiment proved the positive effect of brown coal on the immobilization of heavy metals in the soil even at the lowest application rate, and strengthened that Balinka coal can be applied in the remediation technologies.

Most relevant results of the field experiments - not presenting all the actually gathered data - can be seen in Tables $4-8$. These data show the effects of Balinka brown coal application either on the yields of the test plants or on the element contents of the test plants and soils of the experiments carried out at the Nagyhörcsök Research Station.

According to the soil analysis (LAKANEN \& ERVIÖ, 1971) the mobile, $\mathrm{NH}_{4-}$ acetate+EDTA soluble $\mathrm{Zn}$ content doubled, while the $\mathrm{Cd}$ content dropped to half in the moderately polluted plots with brown coal application (Table 4). In the plants grown on these plots, a similar tendency was detected. This phenomenon needs some further investigation. It seems that brown coal application can

Table 4

Effect of Balinka brown coal application on the $\mathrm{NH}_{4}$-acetát + EDTA-soluble average element content of the soil in maize experiment, $\mathrm{mg} / \mathrm{kg}$ plough layer

(Field experiment, calcareous chernozem, Nagyhörcsök, 2000)

\begin{tabular}{|c|c|c|c|}
\hline Element & Control & Coal & LSD $_{5 \%}$ \\
\hline $\mathrm{K}_{2} \mathrm{O}$ & 140 & 144 & 24 \\
$\mathrm{P}_{2} \mathrm{O}_{5}$ & 94 & 102 & 22 \\
$\mathrm{Sr}$ & 35 & 36 & 4 \\
$\mathrm{Zn}$ & 11 & 21 & 4 \\
$\mathrm{Cd}$ & 1.9 & 1.0 & 1 \\
$\mathrm{~Pb}$ & 3.6 & 3.6 & 1.1 \\
$\mathrm{Ni}$ & 2.9 & 3.0 & 0.6 \\
$\mathrm{Cu}$ & 2.8 & 2.8 & 0.6 \\
$\mathrm{Cr}$ & 0.08 & 0.08 & 0.01 \\
\hline
\end{tabular}


increase the soil's $\mathrm{Zn}$ reserve for plant uptake, but at the same time immobilizes the plant available $\mathrm{Cd}$ content.

As it can be seen from the results of the maize experiment conducted in 2000 (Tables 5 and 6), the $40 \mathrm{t} / \mathrm{ha}$ Balinka coal application did not decrease the uptake of essential nutrients and the yield of maize, at the same time, however, it considerably decreased the uptake of $\mathrm{Sr}$ and $\mathrm{Cd}$ cations in the vegetative parts of the maize crop.

Coal application drastically decreased the toxicity of the Se-loaded soils on barley yield: while in the control plots (without coal application) the plant died out completely in case of the highest Se load, in the coal treated plots with the same Se load $2.11 \mathrm{t} /$ ha grain yield was obtained. Se was applied in spring 1991 in the form of $\mathrm{Na}_{2} \mathrm{SeO}_{3}$.

Table 5

Effect of Balinka brown coal application on the average element content of air dry maize leaf at flowering (Field experiment, calcareous chernozem, Nagyhörcsök, 2000)

\begin{tabular}{|l|r|r|c|}
\hline Element & Control & Coal & LSD $_{5 \%}$ \\
\hline $\mathrm{N} \%$ & 2.45 & 2.50 & 0.14 \\
$\mathrm{~K} \%$ & 2.30 & 2.30 & 0.18 \\
$\mathrm{Ca} \%$ & 0.78 & 0.76 & 0.09 \\
$\mathrm{Mg} \%$ & 0.24 & 0.25 & 0.02 \\
$\mathrm{P} \%$ & 0.25 & 0.25 & 0.02 \\
$\mathrm{Zn} \mathrm{mg} / \mathrm{kg}$ & 41.20 & 47.80 & 9.00 \\
$\mathrm{Sr} \mathrm{mg} / \mathrm{kg}$ & 27.70 & 21.00 & 2.00 \\
$\mathrm{Cd} \mathrm{mg} / \mathrm{kg}$ & 0.54 & 0.16 & 0.02 \\
\hline
\end{tabular}

Table 6

Effect of Balinka brown coal application on the average element content of maize yield at harvest* (Field experiment, calcareous chernozem, Nagyhörcsök, 2000)

\begin{tabular}{|l|c|c|c|c|c|c|}
\hline \multirow{2}{*}{$\begin{array}{l}\text { Element } \\
\text { content }\end{array}$} & \multicolumn{3}{|c|}{ Stem } & \multicolumn{3}{c|}{ Grain } \\
\cline { 2 - 7 } & Control & Coal & LSD $_{5 \%}$ & Control & Coal & LSD $_{5 \%}$ \\
\hline $\mathrm{K} \%$ & 0.86 & 0.88 & 0.14 & 0.36 & 0.35 & 0.02 \\
$\mathrm{Mg} \%$ & 0.24 & 0.21 & 0.07 & 0.11 & 0.12 & 0.01 \\
$\mathrm{P} \mathrm{mg} / \mathrm{kg}$ & 310 & 327 & 51 & 0.23 & 0.26 & 0.03 \\
$\mathrm{Zn} \mathrm{mg/kg}$ & 30 & 33 & 6 & 23 & 22 & 4 \\
$\mathrm{Sr} \mathrm{mg} / \mathrm{kg}$ & 28 & 23 & 3 & 0.22 & 0.14 & 0.09 \\
$\mathrm{Cu} \mathrm{mg/kg}$ & 7.06 & 6.20 & 0.92 & 1.10 & 0.91 & 0.26 \\
$\mathrm{Cd} \mathrm{mg/kg}$ & 0.63 & 0.30 & 0.11 & 0.01 & 0.00 & 0.01 \\
$\mathrm{~Pb} \mathrm{mg/kg}$ & 0.60 & 0.62 & 0.08 & 0.00 & 0.00 & 0.00 \\
$\mathrm{Ni} \mathrm{mg/kg}$ & 0.26 & 0.23 & 0.07 & 0.51 & 0.39 & 0.13 \\
$\mathrm{Cr} \mathrm{mg} / \mathrm{kg}$ & 0.22 & 0.22 & 0.05 & 0.11 & 0.14 & 0.06 \\
\hline
\end{tabular}

*Average grain yield 10 t/ha without treatment's effect 
As it can be seen from the plant analysis data (Table 7), the Cr and Se uptake of plants decreased by $1 / 3$ with coal application. This fact is extremely important, because the Se element remains in mobile and toxic form in similar calcareous soils in Hungary for a long time. Brown coal application can be used effectively for soil remediation especially in the case of Se contamination. In the barley stem, there was a $1 / 3$ decrease in $\mathrm{Cr}$ concentration (as compared to the control treatment), and Se concentration decreased by $9 / 10$, namely by one order of magnitude, due to the effect of coal application.

In the maize experiment with $\mathrm{Zn}$ treatment the average $\mathrm{Sr}$ content of the 6leaf stage shoot decreased statistically by $13 \%$, and the Cd content by $67 \%$,

Table 7

Effect of Balinka brown coal application on the grain yield and element content of barley (Field experiment, calcareous chernozem soil, Nagyhörcsök, 2000)

\begin{tabular}{|c|c|c|c|c|c|c|}
\hline \multirow{2}{*}{ Treatment } & \multicolumn{4}{|c|}{ Se load, kg/ha in 1991.} & \multirow{2}{*}{$\mathrm{LSD}_{5 \%}$} & \multirow{2}{*}{ Mean } \\
\hline & 0 & 30 & 90 & 270 & & \\
\hline \multicolumn{7}{|c|}{ Grain yield (DM) t/ha } \\
\hline Coal & 5.07 & 5.67 & 5.31 & 2.11 & & 4.54 \\
\hline Control & 5.00 & 6.43 & 4.64 & $*$ & 2.00 & 4.02 \\
\hline \multicolumn{7}{|c|}{$\mathrm{Cd} \mathrm{mg/kg}$} \\
\hline Coal & 0.05 & 0.03 & 0.04 & 0.06 & & 0.04 \\
\hline Control & 0.04 & 0.02 & 0.06 & $*$ & 0.04 & 0.04 \\
\hline \multicolumn{7}{|c|}{$\mathrm{Cr} \mathrm{mg/kg}$} \\
\hline Coal & 0.28 & 0.29 & 0.39 & 0.56 & & 0.38 \\
\hline Control & 0.32 & 0.37 & 0.56 & $*$ & 0.13 & 0.42 \\
\hline \multicolumn{7}{|c|}{$\mathrm{Pb} \mathrm{mg/kg}$} \\
\hline Coal & 0.80 & 0.49 & 0.50 & 0.34 & & 0.53 \\
\hline Control & 0.54 & 0.74 & 0.34 & $*$ & 0.2 & 0.40 \\
\hline \multicolumn{7}{|c|}{ Ni $m g / k g$} \\
\hline Coal & 1.1 & 1.2 & 1.4 & 1.0 & & 1.2 \\
\hline Control & 1.2 & 0.2 & 0.5 & $*$ & 0.7 & 0.6 \\
\hline \multicolumn{7}{|c|}{$\mathrm{Cu} \mathrm{mg} / \mathrm{kg}$} \\
\hline Coal & 7.0 & 7.6 & 9.1 & 9.0 & & 8.2 \\
\hline Control & 7.0 & 6.1 & 7.2 & $*$ & 2.2 & 6.8 \\
\hline \multicolumn{7}{|c|}{$\mathrm{Zn} \mathrm{mg/kg}$} \\
\hline Coal & 16 & 19 & 18 & 17 & & 18 \\
\hline Control & 17 & 18 & 16 & $*$ & 4 & 17 \\
\hline \multicolumn{7}{|c|}{ Se $m g / k g$} \\
\hline Coal & 1 & 30 & 131 & 612 & & 194 \\
\hline Control & 1 & 55 & 455 & $*$ & 26 & 170 \\
\hline
\end{tabular}

* No harvestable yield because of Se toxicity; Remark: $\mathrm{Se}$ as $\mathrm{Na}_{2} \mathrm{SeO}_{3}$ ploughed into the soil in 1991 
namely by $2 / 3$ in the coal treated plots, either in the strongly or moderately polluted soils. These data also strengthen the results obtained in the previous year. The Cd uptake by the plant as well as the food chain load can be decreased drastically or stopped with the application of Balinka brown coal (Table 8).

Table 8

Effect of Balinka brown coal application on the element content of the air dry 6-leaf shoot of maize (Field experiment, calcareous chernozem soil, Nagyhörcsök, 2001)

\begin{tabular}{|c|c|c|c|c|c|c|c|c|}
\hline \multirow{2}{*}{$\begin{array}{c}\mathrm{Zn} \\
\mathrm{kg} / \mathrm{ha}^{*}\end{array}$} & Control & Coal & Control & Coal & Control & Coal & Control & Coal \\
\hline & \multicolumn{2}{|c|}{$\mathrm{N} \%$} & \multicolumn{2}{|c|}{$\mathrm{K} \%$} & \multicolumn{2}{|c|}{$\mathrm{P} \%$} & \multicolumn{2}{|c|}{$\mathrm{Mg} \%$} \\
\hline 0 & 3.6 & 3.4 & 4.6 & 5.1 & 0.40 & 0.41 & 0.21 & 0.22 \\
\hline 100 & 3.5 & 3.6 & 5.1 & 5.1 & 0.43 & 0.41 & 0.21 & 0.21 \\
\hline 200 & 3.5 & 3.6 & 5.0 & 4.7 & 0.43 & 0.38 & 0.21 & 0.20 \\
\hline Average & 3.5 & 3.5 & 4.9 & 5.0 & 0.42 & 0.40 & 0.21 & 0.21 \\
\hline $\mathrm{LSD}_{5 \%}$ & \multicolumn{2}{|c|}{0.2} & \multicolumn{2}{|c|}{0.3} & \multicolumn{2}{|c|}{0.03} & \multicolumn{2}{|c|}{0.02} \\
\hline
\end{tabular}

\begin{tabular}{|c|c|c|c|c|c|c|c|c|}
\hline \multirow{2}{*}{$\begin{array}{c}\mathrm{Zn} \\
\mathrm{kg} / \mathrm{ha}^{*}\end{array}$} & Control & Coal & Control & Coal & Control & Coal & Control & Coal \\
\hline & \multicolumn{2}{|c|}{$\mathrm{Zn} \mathrm{mg/kg}$} & \multicolumn{2}{|c|}{$\mathrm{Sr} \mathrm{mg} / \mathrm{kg}$} & \multicolumn{2}{|c|}{$\mathrm{Cd} \mathrm{mg/kg}$} & \multicolumn{2}{|c|}{$\mathrm{Cd} \mathrm{mg/kg} \mathrm{**}$} \\
\hline 0 & 40 & 37 & 35 & 31 & 1.4 & 0.5 & 5.7 & 1.9 \\
\hline 100 & 81 & 84 & 40 & 30 & 1.6 & 0.5 & 6.8 & 2.5 \\
\hline 200 & 72 & 83 & 39 & 38 & 1.4 & 0.5 & 6.2 & 1.9 \\
\hline Average & 64 & 68 & 38 & 33 & 1.5 & 0.5 & 6.2 & 2.1 \\
\hline $\mathrm{LSD}_{5 \%}$ & \multicolumn{2}{|c|}{4} & \multicolumn{2}{|c|}{4} & \multicolumn{2}{|c|}{0.4} & \multicolumn{2}{|c|}{1.3} \\
\hline
\end{tabular}

* As $\mathrm{ZnSO}_{4}$ during the 26 years applied; ** $70 \mathrm{~kg} / \mathrm{ha} \mathrm{Cd}$ load in spring 2001

Mention should be made that oil rape was grown on the Se loaded soil in 2001. Without presenting the detailed results of this experiment, it could be observed that due to coal application the Se toxicity of rape not only stopped but the maximum yield was gained. The oil rape plants produced a high amount of green biomass, and an especially great improvement was detected during the ripening phase in the coal treated plots, hopefully due to the better moisture regime conditions of the treated soils.

No significant changes were found in the microelement content of the rape yield, but in the case of the highest Se load with coal treatment the Se content in the soil decreased considerably. As far as the grain yield of rape is concerned, similar tendencies were detected as in the stems, and the $\mathrm{Sr}$ content decreased due to coal application. The average $\mathrm{Cr}$ content of rape yield decreased from 1.8 to $1.4 \mathrm{mg} / \mathrm{kg}$ in the coal treated plots, and it remained below the $0.1 \mathrm{mg} / \mathrm{kg}$ detection limit in control soil. 


\section{Summary}

In the field experiments carried out in 2000 and 2001 at the Nagyhörcsök Experimental Station on calcareous chernozem soil contaminated with heavy metals the results show that the application of $40 \mathrm{t} / \mathrm{ha}$ Balinka brown coal did not decrease the uptake of essential elements by the maize, barley and rape test plants, and did not decrease the fertility of soil. There was no change or sometimes a slight increase in the investigated tissues of the plants due to the effect of coal application. This is advantageous in $\mathrm{Zn}$ deficient soils, but on similar soils strongly polluted with $\mathrm{Zn}$ the Balinka brown coal cannot be used as an effective remediator.

The coal treatment drastically decreased the Se toxicity of the soil, the maximum yield could even be obtained on the strongly Se-polluted plots. The development of plant stands in the coal treated plots improved considerably, perhaps due to the better moisture regime conditions of the soil.

The $\mathrm{Sr}$ and $\mathrm{Cd}$ content in plant tissues decreased in several cases due to brown coal application. The most dangerous contaminant, the $\mathrm{Cd}$ concentration in the plants dropped to half or even $1 / 3$, as a result of coal treatment.

The results of the two-year experiments showed that the $40 \mathrm{t} / \mathrm{ha}$ rate of Balinka brown coal can be used successfully and economically in the in situ remediation of $\mathrm{Cd}, \mathrm{Se}$ and $\mathrm{Sr}$ contaminated soils. This rate does not influence the original fertility parameters of the soil, but can be applied with advantages both in extremely light- or heavy textured soils in case of moderate contamination. However, further investigations are needed to find out the effects of Balinka-type brown coal application on other soil types, plants and other polluting elements.

Key words: heavy metals, plant uptake, brown coal application

\section{References}

KÁDÁR, I., 1995. Effect of heavy metal load on soil and crop. Acta Agron. Hung. 43. 59-64.

KÜHNERT, M., FUCHS, V. \& GOLBS, S., 1989. Pharmacologisch-toxicologische Eigenschaften von Huminsäures und ihre Wirkungsprofile. Therapie Deutsche Tierärzliche Wochenschrift. 96. (1) 3-4.

LAKANEN, E. \& ERVIÖ, R., 1971. A comparison of eight extractants for the determination of plant available micronutrients in soil. Acta Agr. Fenn. 123. 223-232.

VADÁsZ, J., 1997. Humic and fulvic acids in plant physiological processes. (In Hungarian) PRI-KOMP Kft. Veszprém.

VERMES, L. \& KÁDÁR, I., 2001. Small plot experiments for developing soil remediation technologies. (In Hungarian) Terminal Report of Project KÜ-722-85. 02202/1999 OMFB. Szent István University, Faculty of Horticultural Sciences. Budapest. 